\begin{tabular}{lr}
\hline PRACE NAUKOWE UNIWERSYTETU EKONOMICZNEGO WE WROCEAWIU \\
RESEARCH PAPERS OF WROCLAW UNIVERSITY OF ECONOMICS & nr 482・2017 \\
\hline Wrocław Conference in Finance: Contemporary Trends and Challenges & ISSN $1899-3192$ \\
& e-ISSN $2392-0041$
\end{tabular}

Karolina Zofia Kapuścińska

Lodz University of Technology

e-mail: karolina.kapuscinska@p.lodz.pl

\title{
THE METHOD OF DOCUMENTING RISK \\ MANAGEMENT IN A SELECTED PUBLIC HIGHER EDUCATION INSTITUTION OF THE ŁÓDŹ REGION*
}

\section{SPOSÓB DOKUMENTOWANIA ZARZĄDZANIA RYZYKIEM W WYBRANEJ PUBLICZNEJ SZKOLE WYŻSZEJ Z REGIONU LÓDZKIEGO}

DOI: $10.15611 /$ pn.2017.482.07

JEL Classification: H83

\begin{abstract}
Summary: Nowadays in public institutions environment there are appearing new law restrictions, among them the Ministerial Public Finance Act, according to which public institutions have to lead the risk management process [Winiarska, Postuła 2012]. The aim of this process is to deliver information needed for decision making [Widener 2007] in those units who act their role through tasks in the area of public security [Wieteska-Rosiak 2011], health protection, education [Burnett 2007]. This is connected with building the awareness that risk, understood as all situations that may takes place in institutions with a specific probability [Asel 2009], as well, as situations, which are estimated to involve a threat [Rosa 1998]. It is combined with all the activities of the institution [Ochmańska, Jarząbek 2012]. In this article, the author presented the risk management process in purposefully selected public higher education institution [Huber 2009] from Łódź Region. The aim of the article is to present the process and supplement it with the author's own study results. The research was funded from NCN fund (DEC-2012/07/N/HS4/00274).
\end{abstract}

Keywords: risk, risk management, management control, public institution, higher education institution.

Streszczenie: Obecnie, w środowisku instytucji publicznych pojawiają się nowe restrykcje prawne, w tym Ustawa o finansach publicznych, zgodnie z którą instytucje publiczne muszą prowadzić proces zarządzania ryzykiem [Winiarska, Postuła 2012]. Celem tego procesu jest dostarczenie informacji potrzebnych do podejmowania decyzji [Widener 2007] w tych jednostkach, które pełnią swoją rolę poprzez zadania w zakresie bezpieczeństwa publicznego [Wieteska-Rosiak 2011], ochrony zdrowia, edukacji [Burnett 2007]. Wiąże się ono z budowaniem świadomości, że ryzyko jest interpretowane jako wszystkie te sytuacje, które mogą odbywać się w organizacjach ze specyficznym prawdopodobieństwem [Asel

${ }^{*}$ The project was financed with funds from the Polish National Science Centre granted pursuant to the decision no. DEC-2012/07/N/HS4/00274. 
2009], ale także jako sytuacje, które według szacunków stanowią zagrożenie [Rosa 1998]. Jest ono związane z wszelkimi aktywnościami w instytucji [Ochmańska, Jarząbek 2012]. W niniejszym artykule autor przedstawił proces zarządzania ryzykiem w celowo wybranej publicznej uczelni wyższej [Huber 2009] z Regionu Łódzkiego. Celem artykułu jest prezentacja procesu i uzupełnienie go o wyniki badań własnych autora. Badania ufundowano ze środków NCN (DEC2012/07/N/HS4/00274).

Słowa kluczowe: ryzyko, zarządzanie ryzykiem, kontrola zarządcza, instytucja publiczna, uczelnia wyższa.

\section{Introduction}

Risk management concept comes from the management control. It means all activities undertaken to ensure that objectives and tasks of the institution are realized in a manner consistent with the law, effective, efficient, cost-effective and on time. It originates with the process approach to management and relates primarily to coordination of the allocation of resources, the increase of motivation and performance measurement [Maciariello, Kirby 1994]. The analysis and assessment of risks at public sector institutions plays a key role primarily in the selection of the appropriate control activities. Any control system can only respond properly to the risks for which it was created [Domokos et al. 2015].

Historical experience shows that there is no simple and universal recipe for risk management [Klinke, Renn 2002]. It includes all activities that enable the probability of risk occurring or its impact to be eliminated or reduced to an acceptable level [Vasvári 2015].

In literature about risk management there are lots of definitions of risk. One of them is from ISO 31000. Risk is the impact of uncertainty on objectives, whether this impact is positive or negative. The idea of risk management is not to eliminate risk, since this is impossible, but rather to decide which risks are worth taking and which ones we want to avoid completely. Risk management as described in Hubbard [2009] is the identification, assessment and prioritization of risks, followed by a coordinated and economical application of resources to minimize, monitor and control the probability and/or the impact of unfortunate events. That is why risk can be seen as the product of the probability of an event occurring and the consequences of that event [Schoeman, Vlok 2014]. It can be associated with the objectives which are assigned to be gained by the institution.

Assuming that all objectives are important and that these objectives are subject to uncertainty, there is risk in all institutions. After the literature review the following research hypothesis was formulated: The filling of the documentation about the risk process is linked to the level of its implementation in the institution. A first step that an institution can take is the recognition of risk. Further understanding of risk means understanding what degree of departure from the objective an outcome may take [Luko 2013]. 


\section{The way of risk management functioning among public institutions}

Based on statutory requirements, public entities are subject to the obligation of operating a risk management system as part of the management control system.

This entails the process of identifying risks through their analysis and assessment to instigating measures. Risk management is the major mechanism of efficient control, when it is construed as a response to risks to the institutional goals [Domokos et al. 2015].

The reform of the public sector's control systems was one of the challenges associated with the accession of Poland to the European Union in 2004. Since the Polish public sector was to become a major beneficiary of the EU structural funds, the European Commission requested the distribution of these funds and the effects of their use to be systematically controlled. Chapter 28 of the preaccession negotiations specified that Poland would implement a decentralised control system based on Public Internal Financial Control, a framework developed by the European Court of Auditors. Then, the Minister of Finance decided to broaden the scope of the system to include all of the public sector [Klimczak, Pikos 2013].

Since 2010 the new management control system has become compulsory for all public institutions [The Public Finance Act 2009]. According to the Art. 9 of the Public Finance Act, polish public finance sector entails: public authorities, including government bodies, state control and law enforcement, courts and tribunals, local government units and their associations, budgetary units, government budgetary establishments, executive agencies, budget economy institutions, state funds, Social Insurance Institution (ZUS), National Health Fund (NFZ), independent public health care, public higher education institutions, Polish Academy of Sciences and its institutional units, state and local cultural institutions and other state or local government legal entities established under separate acts for public tasks execution, with the exception of enterprises, research and development units, banks and commercial companies [The Public Finance Act 2009, Art. 9].

In Poland, nowadays the main aim is to educate people and prepare them for future work. It is an action taken by universities all over the country. For this article, the subject of empirical research was one of the public higher education institutions from the Łódź Region.

\section{Description of a chosen public higher education institution of the Lódź Region and the research method}

The chosen public higher education institution of the Łódź Region was inaugurated on October 1, 2002 as a merger of two Schools [Act of July 27 2002, Art. 1]. It is the largest state-owned medical university in Poland whose mission is: educating students in medicine, dentistry, pharmacy and medicine-allied disciplines; educating 
research staff and conducting research work; conducting postgraduate training of highly qualified health care system staff; participating in health care programs set by the social health care system [Medical University of Lodz 2015].

The concept of up-to-date and comprehensive professional training of medical manpower is being improved all the time. The process of education is focused on preparing specialists for work in various communities and national health care systems. Its educational offer, gradually and consequently modified and widened, is adjusted to the requirements laid down in the resolutions validated by Polish Government within the European Union co-operation. Following Poland's entry into the European Union on May 1, 2004 the University offers an automatic recognition of the degree for most of the faculties within all 25 countries of the European Union.

The University employs almost 1,600 research and didactic staff, including over 300 independent researchers, i.e. 170 full professors, 190 assistant and associate professors, as well as nearly $900 \mathrm{PhD}$ academics. Its educational programs arouse great interest among Polish and international students.

Currently, over 8,000 Polish students are receiving their education within medical and medicine-related areas at various faculties. University's education offer also comprises advanced studies at the Faculty of Postgraduate Training with over 300 postgraduate students commencing their education each year. Medical teaching in English was initiated in 2003/2004. Presently about 300 foreign students from various countries (USA, Canada, Taiwan, Sweden, Norway, Great Britain, Spain, Kenia, Nigeria, Zambia) attend medical and dental courses. The University is one of the leading medical research centres in Poland. In one academic year over a hundred research grants are awarded, as well as numerous research contracts. At present, over 300 individual research projects are being conducted, of which over 100 are new ones and more than 200 are continued.

The International Research Programmes team collaborates with University researchers, local enterprises and any international units and institutions that are interested in research cooperation, with special regard to the EU 7 Framework and Public Health Programmes [Medical University of Lodz 2015].

The University has been carrying an extensive international scientific cooperation [Medical University of Lodz 2015]. The empirical research ${ }^{1}$ was conducted by using a research technique of the formal and content analysis of documents. The sources of information were official Statements about the state of management control - the part about risk management [Medical University of Lodz 2011-2014] prepared by the chief executive of the chosen institution and the University Risk Management Policy [Medical University of Lodz 2011] presented on the Public Information Bulletin university website.

${ }^{1}$ The research was funded from National Science Centre fund allocated of the decision number DEC-2012/07/N/HS4/00274. 
First step of the study was the analysis of Statements [Medical University of Lodz 2011-2014], which are formal documents prepared by the university authorities every year. The document contains various pieces, including the presentation of management control sources - among which is the risk management process. When the authorities decide that the level of management control was not sufficient, they are obliged to find exceptions from the process, present future actions which can build an efficient management control level and also fill in a table about the actions which took place in the recent year, but were not planned.

Among those pieces the most important for this article is the risk management process. Another studied document was the University Risk Management Policy [Medical University of Lodz 2011] presented by university authorities and published in 2011. It contains ten parts and ten attachments. The Policy sets out the University's approach to risk and its management together with the means for identifying, analysing and managing risk in order to minimize its frequency and impact [Medical University of Lodz 2011].

The risks considered significant to the ability to achieve its objectives are set out in the corporate section of the risk register [Medical University of Lodz 2011], which incorporates actions for dealing with those risks. The section is monitored on a monthly basis and is updated by nominated groups to take account of the changing environment and circumstances. The key to understanding the risk management policy in the surveyed university is the Second Chapter of the document, in accordance with the provisions of the basis for the sought risks are the mission, vision, strategic and operational objectives defined in the strategy.

The risk management policy is designed to identify potential events that may affect the activities of the university as risk or chances, maintaining the identified risks within the limits and ensuring effective implementation of the objectives set out in the university's development strategy. The risk management policy is a management tool for the authorities of the university and provides guidance for all university employees.

\section{Research results}

The empirical research was conducted from June to July 2015. The aim of the research was to present the method of documentation used by the authorities from one of the public higher education institutions of the Łódź Region.

First part of the study was a formal analysis of the statements about the management control for years 2011, 2012, 2013 and 2014. Most relevant for this paper is the part connected with risk management. As presented in Table 1, risk management is a process leaded by the authorities all through the years of the documentation research period.

Unfortunately, university authorities see a problem with full implementation of the risk management system to everyday activity. As mentioned above, there 
Table 1. Analysis of the statements about management control - pieces about risk management

\begin{tabular}{|c|c|c|c|c|}
\hline \multirow{2}{*}{$\begin{array}{l}\text { Information from the authorities' } \\
\text { statement - area of risk }\end{array}$} & \multicolumn{4}{|c|}{ Year of statement publication } \\
\hline & 2011 & 2012 & 2013 & 2014 \\
\hline $\begin{array}{l}\text { A source of information for } \\
\text { management control takes into account } \\
\text { the risk management process }\end{array}$ & no & yes & yes & yes \\
\hline $\begin{array}{l}\text { Exception in training and enhancing } \\
\text { employees' knowledge of risk } \\
\text { management }\end{array}$ & yes & yes & no & no \\
\hline $\begin{array}{l}\text { Exception in risk management } \\
\text { documenting system }\end{array}$ & yes & yes & yes & no \\
\hline $\begin{array}{l}\text { A comprehensive risk management } \\
\text { process is being planned }\end{array}$ & yes & yes & yes & yes \\
\hline $\begin{array}{l}\text { Workshops and trainings for workers } \\
\text { in the field of risk management are being } \\
\text { planned }\end{array}$ & no & yes & yes & yes \\
\hline $\begin{array}{l}\text { Actions taken to improve risk } \\
\text { management, including authorities, } \\
\text { statements }\end{array}$ & yes & no & no & no \\
\hline $\begin{array}{l}\text { Actions taken to improve risk } \\
\text { management, including workshops and } \\
\text { training sessions for employees }\end{array}$ & no & yes & yes & yes \\
\hline $\begin{array}{l}\text { Actions taken last year to improve risk } \\
\text { management, including performance of } \\
\text { a complex risk management process }\end{array}$ & no & $\begin{array}{l}\text { yes - only } \\
\text { on strategic } \\
\text { level }\end{array}$ & $\begin{array}{l}\text { yes -only } \\
\text { on strategic } \\
\text { level }\end{array}$ & $\begin{array}{l}\text { yes }- \text { e.g. } \\
\text { in project } \\
\text { management }\end{array}$ \\
\hline
\end{tabular}

Source: own study based on the [Medical University of Lodz 2011-2014].

were some exceptions in risk management in years 2011-2014. They were connected with preparing employees to identify risk, teach them how to find and document risk. That is why not only in 2011, but also in 2012, 2013 and 2014 university authorities wanted to plan a comprehensive risk management process. They planned and made some actions to improve this process, such as - developing the University Risk Management Policy, organizing workshops, case studies on project management.

For implementation of risk awareness, authorities of the surveyed public higher education institution decided to take formal steps about the risk. In 2011, they presented the University Risk Management Policy, which is a basis for risk management. In this document the whole process, divided into few steps, is presented. Table 2 presents the method of documenting each risk management subprocess.

The whole risk management process is supervised not only by the university authorities, but also by an administrative employee hired on the post of risk management. This person is responsible for collecting the whole documentation 
Table 2. The method of documenting the risk management sub-process

\begin{tabular}{|c|c|c|c|}
\hline $\begin{array}{c}\text { Risk } \\
\text { management }\end{array}$ & \multicolumn{2}{|c|}{ Main focus } & \multirow{2}{*}{$\begin{array}{c}\text { Content } \\
4\end{array}$} \\
\hline 1 & 2 & 3 & \\
\hline Definition & $\begin{array}{l}\text { presentation of the } \\
\text { dictionary about risk (part } \\
\text { one of the document) }\end{array}$ & & $\begin{array}{l}\text { determining goals, the } \\
\text { economic and legislative } \\
\text { environment, affected } \\
\text { processes and activities, and } \\
\text { recording the expected state }\end{array}$ \\
\hline Identification & $\begin{array}{l}\text { brain storming, experience } \\
\text { and predictions, other } \\
\text { methods, statistical or } \\
\text { non-statistical }\end{array}$ & $\begin{array}{l}\text { each employee may } \\
\text { announce risks } \\
\text { identified in their unit } \\
\text { to the chief executive }\end{array}$ & $\begin{array}{l}\text { identification of risks and } \\
\text { opportunities that may } \\
\text { influence the achieving the } \\
\text { institutional goals }\end{array}$ \\
\hline $\begin{array}{l}\text { Evaluation and } \\
\text { Verification }\end{array}$ & $\begin{array}{l}\text { significance of each } \\
\text { risk, in a scale of } 1-5 \\
\text { the probability of risk } \\
\text { appearance and in the } \\
\text { same scale the impact of } \\
\text { each risk on the institution } \\
\text { (on strategic, operational, } \\
\text { project levels) }\end{array}$ & $\begin{array}{l}\text { each risk is } \\
\text { a combination of the } \\
\text { probability and impact } \\
\text { and after calculating } \\
\text { it, the visual effect is } \\
\text { a risk map }\end{array}$ & $\begin{array}{l}\text { searching for the resources } \\
\text { used to keep risk on the } \\
\text { acceptable level }\end{array}$ \\
\hline $\begin{array}{l}\text { Analysis and } \\
\text { Prioritization } \\
\text { of risks }\end{array}$ & & $\begin{array}{l}\text { the priority is measured } \\
\text { on a scale from } 1 \text { to } 4, \\
\text { where } 1 \text { is the lowest, } \\
4 \text { is the biggest value }\end{array}$ & $\begin{array}{l}\text { using two characteristics } \\
\text { of risk - probability and } \\
\text { impact of risk on the } \\
\text { institution }\end{array}$ \\
\hline \multirow[t]{5}{*}{$\begin{array}{l}\text { Definition of } \\
\text { acts with non- } \\
\text {-acceptable risk }\end{array}$} & risk transfer & \begin{tabular}{|l|} 
minimize the \\
probability and impact \\
with insurance, \\
outsourcing some \\
activities which are \\
associated with risk
\end{tabular} & \multirow[t]{5}{*}{$\begin{array}{l}\text { preparing few types of } \\
\text { a reaction }\end{array}$} \\
\hline & risk reduction & $\begin{array}{l}\text { minimize risk to an } \\
\text { acceptable level }\end{array}$ & \\
\hline & acceptance of risk & $\begin{array}{l}\text { in case of difficulties } \\
\text { in minimizing the risk } \\
\text { level or in case of high } \\
\text { costs of risk reduction }\end{array}$ & \\
\hline & risk avoidance & $\begin{array}{l}\text { avoid the activities } \\
\text { associated with risk }\end{array}$ & \\
\hline & $\begin{array}{l}\text { using the positive } \\
\text { realisations of risk }\end{array}$ & & \\
\hline $\begin{array}{l}\text { Definition of } \\
\text { acts with using } \\
\text { the opportunities }\end{array}$ & & & $\begin{array}{l}\text { preparing few ways } \\
\text { of reaction }\end{array}$ \\
\hline
\end{tabular}




\begin{tabular}{|c|c|c|c|}
\hline 1 & 2 & 3 & 4 \\
\hline Risk improvers & & & $\begin{array}{l}\text { preparing a list of people } \\
\text { who will be responsible for } \\
\text { scheduling and taking risk- } \\
\text {-corrective actions }\end{array}$ \\
\hline \multirow[t]{5}{*}{$\begin{array}{l}\text { Monitoring and } \\
\text { Control }\end{array}$} & $\begin{array}{l}\text { risk documentation for } \\
\text { project whose value is } \\
\text { more than } 2 \text { million must } \\
\text { be accepted by the Rector }\end{array}$ & & \multirow[t]{5}{*}{$\begin{array}{l}\text { preparing tables for } \\
\text { monitoring and reporting } \\
\text { about risk management in } \\
\text { the institution }\end{array}$} \\
\hline & low risk & $\begin{array}{l}\text { acceptable risk must } \\
\text { be monitored and from } \\
\text { time to time verified by } \\
\text { control mechanisms }\end{array}$ & \\
\hline & medium risk & $\begin{array}{l}\text { needs to be monitored, } \\
\text { and it can be tolerated } \\
\text { only in situations } \\
\text { when the costs of risk } \\
\text { improvement are not } \\
\text { very high }\end{array}$ & \\
\hline & high risk & $\begin{array}{l}\text { in extraordinary } \\
\text { situations only the } \\
\text { Rector may accept this } \\
\text { risk level }\end{array}$ & \\
\hline & every year control & $\begin{array}{l}\text { the self- } \\
\text {-assessment report on } \\
\text { risk prepared by the } \\
\text { Rector, Dean, chief } \\
\text { executives, project } \\
\text { managers }\end{array}$ & \\
\hline
\end{tabular}

Source: own study based on [Medical University of Lodz 2011].

prepared by the employees about the identification, evaluation, verification, analysis and monitoring of risk. Together with this person, the Rector decides which risks may have the biggest influence on the university goals.

University Risk Management Policy [Medical University of Lodz 2011] is a basis for risk management. In this document, the institution is divided into three levels: strategic, operational and project. For each level, risk management must be documented.

On a strategic level, the risk management process is controlled once a year. The person in the institution responsible for this level is the Rector. His competencies include preparing of the Risk Management Policy, its implementation and every year evaluation, determining the level of risk appetite. He also publishes and implements risk management procedures inside the institution, identifies and assesses the risks at the strategic level. After strategic analysis, the Rector designates strategical risk 
owners. One of his tasks is also monitoring and control of the interim and yearly reports about risk management. The Rector carries out these activities the with help of Vice Rectors, the Chancellor and Vice Chancellors.

Table 3 presents a strategic level risk register.

Table 3. The strategic level risk register

\begin{tabular}{|l|c|c|c|c|c|c|c|c|c|c|c|}
\hline \multicolumn{3}{|c|}{ Institution's name } & \multicolumn{2}{|l|}{ No. } \\
\hline $\begin{array}{c}\text { Strategic } \\
\text { area }\end{array}$ & $\begin{array}{c}\text { Strategic } \\
\text { goal }\end{array}$ & $\begin{array}{c}\text { Risk } \\
\text { category }\end{array}$ & $\begin{array}{c}\text { Risk } \\
\text { factor }\end{array}$ & $\begin{array}{c}\text { Probability } \\
(1-5)\end{array}$ & $\begin{array}{c}\text { Impact } \\
(1-5)\end{array}$ & $\begin{array}{c}\text { Risk } \\
\text { (Probability } \\
\text { times } \\
\text { Impact })\end{array}$ & Priority & $\begin{array}{c}\text { Risk } \\
\text { level }\end{array}$ & $\begin{array}{c}\text { Risk } \\
\text { owner }\end{array}$ & $\begin{array}{c}\text { Mechanisms } \\
\text { of risk reduction }\end{array}$ \\
\hline & & & & & & & & & & \\
\hline
\end{tabular}

Source: own study based on [Medical University of Lodz 2011].

As mentioned above, the Rector - as the highest authority at the university, conducts and improves the implementation of risk management. For this reason, he has a special part to play - he gives priority to each strategic risk. Based on his decision, risk, which has probability of 5 and an impact of 3 on the relevant scales may not be treated as so important in the long-term functioning of the institution. Of course, all the decisions are made after consultation with Vice Rectors, the Chancellor and Vice Chancellors.

The second level of the risk management process in the studied university is the operational level. It is based on the current identification of risks important for the operational goals realization [Komańda 2011]. It also requires making assessments and correct actions. Responsible for this step of the process are the Deans, the managers of each unit of the institution. Among their tasks, one may find identification, evaluation and reduction of the key risks of achieving the operational aims. Risk assessment should include probability and impact of risk. Another task is designing and implementation of the acts which minimize the risk and reduce it to acceptable level, as well as operational risk level monitoring and preparing reports about it. The Deans, the managers of each unit of the institution, are also responsible for ensuring the compliance of acts with the Risk Management Policy in place at the institution, archiving of the documents on the Risk Management Policy realization and ensuring the awareness of the significance of risk management in the institution. Table 4 presents the operational level risk register.

The analysis of risk on the operational level starts with the name of the risk area. In the University Risk Management Policy, there are five areas identified, including: education of students; science, research and development; clinical activities; administration and management; development. The unit's chief executive selects one of the areas and then decides with which goal, as assigned in the documentation, it is associated. 
Table 4. The operational level risk register

\begin{tabular}{|l|c|c|c|c|c|c|c|c|c|c|}
\hline \multicolumn{9}{|c|}{ Institution's name } & \multicolumn{2}{l|}{} \\
\hline No. & $\begin{array}{c}\text { Risk } \\
\text { area }\end{array}$ & Goal & $\begin{array}{c}\text { Risk } \\
\text { category }\end{array}$ & $\begin{array}{c}\text { Risk } \\
\text { factor }\end{array}$ & $\begin{array}{c}\text { Probability } \\
(1-5)\end{array}$ & $\begin{array}{c}\text { Impact } \\
(1-5)\end{array}$ & $\begin{array}{c}\text { Risk } \\
\text { (Probability } \\
\text { times Impact) }\end{array}$ & $\begin{array}{c}\text { Risk } \\
\text { level }\end{array}$ & $\begin{array}{c}\text { Risk } \\
\text { owner }\end{array}$ & $\begin{array}{c}\text { Mechanisms } \\
\text { of risk } \\
\text { reduction }\end{array}$ \\
\hline & & & & & & & & & & \\
\hline
\end{tabular}

Source: own study based on the [Medical University of Lodz 2011].

After that, he/she selects one of the following risk categories: legal, financial, human resources, infrastructure. These three pieces of information are necessary to find the risk factor which may cause a problem for the unit. As mentioned before, each risk has to be measured for the degree of probability and of impact. Deans, unit's chief executives, have to monitor the way of achieving the goals and also have an impact in preparing some activities linked with this. For that reason, they may indicate the owner for each of the identified risks. Their last task is to monitor the risk management, find the mechanisms of risk reduction and prepare interim reports about the state of the process. Of course, there is a designated person at the university, who can help. That person is the administrative employee hired on the post of risk management.

Last level of the risk management process in the studied public higher education institution is the project level. It entails the pre-analysis of the risk factors on the step of project acceptance and also risk analysis after achieving each milestone of the project, as well as taking a corrective action. On this level, the responsible employee is the project manager. She/he has to identify the risk factors associated with the project, assess and prioritize the identified risks, including probability and impact level. His/her tasks include also designing and implementing the corrective action which may reduce the risk to an acceptable level and archiving of documents related to the risk management policy within project realization.

In case of identifying the risk, which may cause interruption in project realization, project managers are obliged to inform their chief executive manager. Table 5 presents the project level risk register.

Table 5. Risk register on the project level

\begin{tabular}{|c|c|c|c|c|c|c|c|c|c|}
\hline \multicolumn{10}{|c|}{ Unit's name } \\
\hline No. & $\begin{array}{c}\text { Goal of the } \\
\text { project }\end{array}$ & $\begin{array}{c}\text { Risk } \\
\text { category }\end{array}$ & $\begin{array}{l}\text { Risk } \\
\text { factor }\end{array}$ & $\begin{array}{c}\text { Probability } \\
\text { (1-5) }\end{array}$ & $\begin{array}{c}\text { Impact } \\
(1-5)\end{array}$ & $\begin{array}{c}\text { Risk } \\
\text { (Probability } \\
\text { times Impact) }\end{array}$ & Risk level & $\begin{array}{c}\text { Risk } \\
\text { owner }\end{array}$ & $\begin{array}{c}\text { Mechanisms } \\
\text { of risk } \\
\text { reduction }\end{array}$ \\
\hline & & & & & & & & & \\
\hline & & & & & & & & & \\
\hline & the Projec & anage & ature & & & & & & \\
\hline
\end{tabular}

Source: own study based on the [Medical University of Lodz 2011]. 
The project level risk register is prepared for each project conducted at the public higher education institution. Each Project Manager is required to be aware of the all risks, not only negative but also positive, which may influence the project. In the studied institution, the authorities decided that the first step in project risk management is to fulfil the goal of the project. This needs to be integrated with the project documents and analysis made before opening the project. Other steps of the analysis on the risk management level are the same as in the operational level. However, the document signed by the Project Manager is required to be presented to two persons - to the Dean or Chief Executive of the unit in which the project is being realized and also to the administrative employee hired on the post of risk management.

The study in the selected public higher education institution presented in the article illustrates the method of documenting the risk management process and its final source, which is the statement about the management control. As presented above, risk management should entangle the whole institution and it requires a significant awareness of risk which may appear on every activity up-taken by the employees.

For this reason, the Rector and the authorities of the surveyed public higher education institution in the Łódź Region decided to divide the implementation of the process into steps. They also created the documents for strategic, operational and project-level risk. Taking above into consideration, in author's opinion, the research confirmed the research hypothesis that the filling of the documentation about the risk process is linked to the level of implementation of the process in the institution.

As mentioned in the first part of the study, the Rector in his statements from 2011, 2012, 2013, 2014 writes that the risk management process is being modified, university employees takes part in the workshops about risk measurement. In his opinion, this part of public higher education institution management is important and he continually cares about the full implementation of the risk management process into every-day activities of the university.

\section{Conclusion}

The risk management process realized by the public units, among which one counts the public higher education institutions, may lead to the increase in management efficiency and to the better use of existing resources, both human and financial. It could also help to improve the quality of education, constructing the ability to utilise emerging opportunities. On one hand, the impact of risk management would be improving the quality and efficiency of project management, including eliminating the risk of project failures, and on the other hand, the elimination of unethical behaviour, waste and fraud. Of course, all actions taken by the authorities of the unit must be associated with new legal requirements and standards. 
The purpose of the University Risk Management Policy is to develop a consistent approach towards risk across the institution and outline the processes for recognising, analysing and dealing with risks, as well as assuring the effectiveness of the identified processes. It is designed to minimize the frequency and impact of adverse incidents arising from risks and to identify improvements in procedures and service delivery, in order to ensure the efficient and effective use of the public funds.

For this reason, all the employees are engaged not only in the implementation, but also in the development of the risk management process. In this article, the way of documenting that process was presented, other aspects of risk management will be the subject of author's further studies.

\section{References}

Act of 27 July 2002 on the establishment of the Medical University of Lodz (Journal of Laws of 2002, No. 141, item 1184).

Asel J.A., 2009, Risk Management and Management Control - The Impact of the Financial Crisis on the Use of Management Control Systems, 18th EDAMBA Summer Academy, Sorèze.

Burnett R., 2007, Recovering the civic university, [in:] McIlrath L., MacLabhrainn J. (eds.), Higher education and civic engagement: international perspectives, Ashgate Publishing, Aldershot, p. 27-35.

Domokos L., Nyéki M., Jakovác K., Németh E., Hatvani C., 2015, Risk Analysis and Risk Management in the Public Sector and in Public Auditing, Public Finance Quarterly, no.1, p. 7-28.

Hubbard, D.W., 2009, The failure of risk management: Why it's broken and how to fix it, John Wiley and Sons, New Jersey.

Huber C., 2009, Risks and Risk-Based Regulation in Higher Education Institutions, Tertiary Education and Management, vol. 15(2), p. 83-95.

Klimczak K.M., Pikos A., 2013, Risk- based management control in the public sector in Poland, Zeszyty Teoretyczne Rachunkowości, vol. 72 (128), p. 6-77.

Klinke A., Renn O., 2002, A New Approach to Risk Evaluation and Management: Risk-Based, Precaution-Based, and Discourse-Based Strategies, Risk Analysis, vol. 22, no. 6, p. 1071-1094.

Komańda M., 2011, Challenges in the implementation of management control on units of the sphere of public finance in Poland, [in:] Ćwiklicki M., Jabłoński M. (ed.), Management consulting. The Central and Eastern Europe Perspective, Cracow University of Economics Foundation, Cracow, p. 112-124.

Luko N., 2013, Reviews of Standards and Related Material Risk Management Principles and Guidelines, Quality Engineering, no. 25, p. 451-454.

Maciariello J., Kirby C., 1994, Management Control Systems - Using Adaptive Systems to Attain Control, Prentice Hall, New Jersey.

Medical University of Lodz, 2011, University Risk Management Policy, http://a.umed.pl/pl/index1. php?dir=inf\&mn=akty_zarzadzenia (17.06.2015).

Medical University of Lodz, 2011-2014, Statements about the state of management control, https://bip. umed.pl/SitePages/DevHome.aspx\#Kontrola_zarzadcza (17.06.2015).

Medical University of Lodz, 2015, History of the MUL, http://a.umed.pl/eng/node/2 (17.06.2015).

Ochmańska L., Jarząbek T., 2012, Organizacja kontroli zarządczej w jednostkach sektora finansów publicznych, [in:] Winiarska K. (ed.), Kontrola zarządcza w jednostkach sektora finansów publicznych, Oficyna Wolters Kluwer Business, Warsaw, p. 102-133. 
Rosa E.A., 1998, Metatheoretical Foundations for Post-Normal Risk, Journal of Risk Research, no. $1(1)$, p. $15-34$.

Schoeman J.S., Vlok P.J., 2014, The possible influence of risk management, forecasting, and personnel training in physical asset management, South African Journal of Industrial Engineering, vol. 25(2), p. 96-104.

The Public Finance Act of the 27th of August 2009, Journal of Laws, No. 157, Item 1240.

Vasvári T., 2015, Risk, Risk Perception, Risk Management - a Review of the Literature, Public Finance Quarterly, no. 1, p. 29-48.

Widener S.K., 2007, An Empirical Analysis of the Levers of Control Framework, Accounting, Organizations and Society, vol. 32/7-8, p. 757-778.

Wieteska-Rosiak B., 2011, Działalność władz publicznych w obszarze bezpieczeństwa publicznego - na przykładzie województwa łódzkiego, Studia Ekonomiczne Regionu Łódzkiego, no. 5.

Winiarska K., Postuła M., 2012, Kontrola zarządcza w systemie kontroli finansów publicznych, [in]: Winiarska K. (ed.), Kontrola zarządcza w jednostkach sektora finansów publicznych, Oficyna a Wolters Kluwer Business, Warsaw, p. 33-45. 